\title{
Correction: Bone marrow MSCs in MDS: contribution towards dysfunctional hematopoiesis and potential targets for disease response to hypomethylating therapy
}

\author{
Zhiyong Poon $^{1} \cdot$ Niraja Dighe ${ }^{1} \cdot$ Subhashree S. Venkatesan $^{1} \cdot$ Alice M. S. Cheung $^{1} \cdot$ Xiubo Fan $^{2} \cdot$ Sudipto Bari $^{1} \cdot$ \\ Monalisa Hota ${ }^{3}$ Sujoy Ghosh ${ }^{3}$. William Y. K. Hwang ${ }^{1,4,5}$
}

(c) The Author(s) 2018. This article is published with open access

\section{Correction to: Leukemia;}

https://doi.org/10.1038/s41375-018-0310-y;

published online: 21 December 2018.

In the original version of this article there was a mistake in the spelling of the author Sujoy Ghosh, originally spelt Sujoy Gosh. This has now been corrected in both the PDF and HTML versions of the article.

These authors contributed equally: Zhiyong Poon, Niraja Dighe

William Y. K. Hwang

william.hwang.y.k@singhealth.com.sg

1 Department of Hematology, Singapore General Hospital, Singapore, Singapore

2 Department of Clinical Translational Research, Singapore General Hospital, Singapore, Singapore

3 Cardiovascular \& Metabolic Disorders and Centre for Computational Biology, Duke-NUS Medical School, Singapore, Singapore

4 National Cancer Center, Singapore, Singapore

5 Cancer \& Stem Cell Biology, Duke-NUS Medical School, Singapore, Singapore
Open Access This article is licensed under a Creative Commons Attribution 4.0 International License, which permits use, sharing, adaptation, distribution and reproduction in any medium or format, as long as you give appropriate credit to the original author(s) and the source, provide a link to the Creative Commons license, and indicate if changes were made. The images or other third party material in this article are included in the article's Creative Commons license, unless indicated otherwise in a credit line to the material. If material is not included in the article's Creative Commons license and your intended use is not permitted by statutory regulation or exceeds the permitted use, you will need to obtain permission directly from the copyright holder. To view a copy of this license, visit http://creativecommons. org/licenses/by/4.0/. 